\title{
Implementasi Model Pembelajaran Problem Solving untuk Meningkatkan Hasil Belajar IPS
}

\author{
Ayu Komang Ratna Dewi ${ }^{1 *}$
}

${ }^{1}$ SMP Negeri 4 Seririt, Singaraja, Indonesia

\author{
A R T I C L E I N F O \\ Article history: \\ Received 09 October 2020 \\ Received in revised form \\ 30 November 2020 \\ Accepted 10 January 2021 \\ Available online 01 \\ February 2021 \\ Kata Kunci: \\ Problem Solving; Hasil \\ Belajar IPS \\ Keywords: \\ Problem Solving; Social \\ Learning Outcomes.
}

\begin{abstract}
A B S T R A K
Kurangnya kemampuan guru dalam menyelenggarakan pembelajaran yang inovatif berdampak pada rendahnya hasil belajar IPS siswa. Oleh sebab itu, diperlukan upaya untuk mengatasi permasalah tersebut. Salah upaya yang dapat dilakukan adalah dengan menerapkan model pembelajaran inovatif. Penelitian ini berujuan untuk meningkatkan hasil belajar IPS siswa melalui implementasi model pembelajaran problem solving. Penelitian ini merupaan jenis penelitian tindakan kelas (PTK). Subjek dalam penelitian ini berjumlah 29 orang terdiri dari 19 siswa laki dan 10 siswa perempuan. Data hasil belajar dalam penelitian ini dikumpulkan dengan menggunakan metode tes. Data tersebut kemudian dianalisis dengan statistik deskriptif. Hasil penelitian menunjukkan bahwa adanya peningkatan rata-rata pada siklus 1 (76,56 menjadi 80,39) pada siklus II, dan persentase ketuntasan dari sebesar $68,97 \%$ pada siklus 1 menjadi $89,66 \%$ pada siklus II. Prolehan data ini sudah mencapai standard ketuntasan yang diharapkan penulis yaitu dengan KKM 70 . Berdasarkan hal tersebut dapat disimpulkan bahwa penerapan model pembelajaran problem solving meningkatkn hasil belajar IPS siswa.
\end{abstract}

\section{A B S T R A K}

The lack of the teacher's ability to organize innovative learning has an impact on the low students' social studies learning outcomes. Therefore, efforts are needed to overcome these problems. One of the efforts that can be done is to apply an innovative learning model. This study aims to improve student social studies learning outcomes through the implementation of problem solving learning models. This research is a type of classroom action research (PTK). Subjects in this study amounted to 29 people consisting of 19 male students and 10 female students. Learning outcome data in this study were collected using the test method. The data were then analyzed using descriptive statistics. The results showed that there was an average increase in cycle 1 (76.56 to 80.39 ) in cycle II, and the percentage of completeness from $68.97 \%$ in cycle 1 to $89.66 \%$ in cycle II. The results of this data have reached the standard of completeness expected by the author, namely the KKM 70. Based on this, it can be concluded that the application of problem solving learning models increases student social studies learning outcomes.

\section{Pendahuluan}

Pendidikan sebagai sarana sosialisasi merupakan kegiatan manusia yang melekat dalam kehidupan masyarakat, sehingga usia pendidikan hampir sama dengan usia manusia dalam berbagai rentang peradaban (Hamdu \& Agustina, 2011; Heriyansyah, 2018). Pendidikan dan pengajaran adalah suatu proses yang sadar tujuan. Tujuan dapat diartikan sebagai suatu usaha untuk memberikan rumusan hasil yang diharapkan siswa setelah melaksanakan pengalaman belajar (Malisa, Bakti, \& Iriani, 2018; Musa, 2016). Tercapai tidaknya tujuan pengajaran salah satunya adalah terlihat dari prestasi belajar yang diraih siswa. Dengan prestasi yang tinggi, para siswa mempunyai indikasi berpengetahuan yang baik (Hamdu \& Agustina, 2011; Suhendri, 2015).

Copyright (C) Universitas Pendidikan Ganesha. All rights reserved 
Pendidikan merupakan suatu proses yang mencakup tiga dimensi, individu, masyarakat atau komunitas nasional dari individu tersebut, dan seluruh kandungan realitas, baik material maupun spiritual yang memainkan peranan dalam menentukan sifat, nasib, bentuk manusia maupun masyarakat (Juhji, 2016; Nurkholis, 2013). Pendidikan dalam kehidupan sehari-hari merupakan bagian dari kehidupan masyarakat dimana proses pendidikan telah ada sejak awal adanya manusia di muka bumi. Secara umum pendidikan diartikan sebagai usaha manusia untuk membina kepribadiannya sesuai dengan nilai-nilai dan budaya masyarakat (Juhji, 2016; Sumiati, 2018).

Pentingnya kepedulian terhadap aspek pendidikan juga ditegaskan dalam ajaran teologis. Sering kita dengar pernyataan_yang diimitasi dari pandangan John Locke_bahwa anak yang baru lahir bagaikan kertas putih (tabula rasa). Karena itu, anak harus dididik dengan cara mengisi kertas putih itu dengan pengetahuan sarat manfaat. menyatakan bahwa setiap anak memiliki potensi multikecerdasan yang harus dibantu pengembangannya melalui pendidikan, sehingga bisa berkembang optimal. Van Eukul dan Kellog, Antropolog, telah melakukan penelitian terhadap anak manusia yang dibiarkan hidup diasuh oleh seekor binatang (Yuliati \& Lestari, 2019). Hasilnya, anak tersebut tidak mampu berkembang sebagaimana "manusia" umumnya (Warsono, 2017).

Pembelajaran Proses belajar mengajar pada umumnya merupakan suatu siklus yang terdiri atas sejumlah komponen yang tersusun secara teratur, berhubungan dan saling mempengaruhi untuk mencapai tujuan belajar yang telah ditetapkan (Herefa, 2020; Irawati, 2014). Komponen-komponen tersebut antara lain: siswa, guru, sumber, media dan lingkungan belajar. Oleh karena itu, untuk meningkatkan kualitas belajar mengajar, maka semua komponen tersebut harus berkualitas. Dalam proses pembelajaran di sekolah, khususnya mata pelajaran IPS terpadu merupakan mata pelajaran yang wajib diberikan secara formal di tingkat SMP dari kelas VII sampai dengan kelas IX, yang dewasa ini dihadapkan pada tantangan untuk mempersiapkan manusia Indonesia yang mampu memerankan diri dalam kehidupan dunia modern dengan perkembangan Ilmu Pengetahuan dan Teknologi (IPTEK) yang makin pesat. IPS sebagai ilmu yang dipadukan dengan ilmu-ilmu lainnya diharapkan dapat menjawab tantangan di atas melalui pembelajaran siswa yang tidak hanya sekedar memperoleh pengetahuan, tetapi juga menemukan sendiri pengetahuan tersebut.

Dengan demikian maka pembelajaran di kelas akan berlangsung efektif serta dapat mencapai tujuan pendidikan yang dimaksud, apabila dikemas dengan strategi, metode dan pendekatan yang sesuai dengan pokok bahasan, juga guru memiliki keterampilan memilih media yang sesuai dengan karakteristik mata pelajaran serta peserta didik. Untuk itu guru semestinya memahami peran, fungsi dan kegunaan mata pelajaran diklat yang diampu. Lebih-lebih dengan adanya pergeseran paradigma pendidikan akibat perkembangan peradaban manusia, yang menuntut kesiapan sumber daya manusia dalam menyongsong perkembangan peradaban dimaksud. Pergeseran yang paling menjolok terkait peran pembelajaran untuk menyediakan sumber daya manusia yang berkualitas adalah kegiatan pengajaran, bergeser menjadi pembelajaran, pergeseran ini memiliki arti bahwa guru tidak lagi memberikan atau menuangkan sejumlah konsep data dan fakta ke dalam otak siswa melalui proses pengajaran, tetapi guru harus mampu menjadi fasilitator belajar bagi siswa sehingga siswa dapat membangun pengetahuannya (fakta, data, konsep) sendiri.

Guru yang kreatif dapat memanfaatkan segala yang ada agar interaksi belajar mengajar dapat berlangsung dengan menyenangkan dan membuat peserta didik termotivasi untuk mengikuti pembelajaran. Guru dapat mengoptimalkan kreativitasnya memotivasi peserta didik baik dari dalam maupun dari luar. Dari dalam misalnya guru harus pandai menjadi pribadi yang dekat dengan peserta didik. Sedangkan dari luar misalnya guru dapat memilih metode yang tepat dan menggunakan media yang sesuai sehingga peserta didik termotivasi untuk belajar Selanjutnya tulisan ini akan menjelaskan tentang teori motivasi, teori belajar, motivasi belajar, kreativitas guru dan bagaimana kreativitas guru meningkatkan motivasi belajar peserta didik (Oktiani, 2017; Purwanti \& Manurung, 2015). Guru dijadikan tumpuan dan kepercayaan yang besar dalam mengubah dan meningkat kualitas peserta didik. Dalam dirinya ada dua fungsi yang tidak bias dipisahkan yaitu mendidik dan mengajar. Mendidik artinya guru mengubah dan membentuk perilaku dan kepribadian peserta didik. Pengetahuan yang diterimanya dari seorang guru bukanlah akhir dari proses pembelajaran, akan tetapi nilai-nilai dalam ilmu pengetahuan diwujudnyatakan dalam kehidupan sehari-hari (Jauhar \& Nurdin, 2017; Juhji, 2016).

Kenyataannya, kondisi pembelajaran di kelas saat ini masih diwarnai dengan kondisi pembelajaran yang belum mendukung perubahan paradigma dimaksud. Dalam pembelajaran, guru masih saja memanfaatkan pendekatan, strategi dan metode yang belum memberdayakan siswa, sehingga aktivitas lebih didominasi oleh aktivitas, kretaivitas dan inisiatif guru (pembelajaran berpusat pada guru). Ketidakmampuan guru dalam mengkaji serta merefleksi kualitas pembelajaran mereka di kelas, serta keengganan melaksanakan inovasi merupakan penguat kondisi pembelajaran kita saat ini. 
Pembelajaran IPS pada kelas VIII-I SMP Negeri 4 Seririt, juga bermasalah seperti umumnya proses pembelajaran yang disebutkan. Dilihat dari siswa, aktivitas dan kreativitas siswa dalam proses pembelajaran, rata-rata sangat rendah dan kecendrungan siswa hanya sebagai penonton guru dalam menyajikan materi pelajaran. Akibatnya rata-rata prestasi belajar yang diperoleh pada ulangan harian yang dilaksanakan awal semester ganjil tahun pelajaran 2019/2020 hanya mencapai 70,87 dengan ketuntasan belajar klasikal 44,83\%. Rata-rata nilai hasil ulangan dan ketuntasan klasikal yang diperoleh tersebut jika diukur dengan KKM ternyata tergolong belum tuntas, karena KKM mata pelajaran IPS pada sekolah ini adalah 70.

Rendahnya kemampuan siswa tersebut disebabkan oleh faktor luar dan faktor dalam baik dari siswa sendiri maupun dari pihak guru. Dari guru yaitu disebabkan oleh metode pembelajaran yang digunakan tidak sesuai dan tidak efektif sehingga proses belajar mengajar cendrung menyebabkan siswa menjadi pasif dalam menerima materi pelajaran sedangkan dari siswa antara lain kurangnya motivasi untuk mempelajari mata pelajaran Ilmu Pengetahuan Sosial (IPS) karena dianggap materinya susah untuk dipelajari dan membosankan. Kedua hal yang telah di uraikan sangat memungkinkan mempengaruhi hasil belajar siswa, khususnya siswa kelas VIII-I.

Salah satu upaya yang dapat dilakukan untuk mengatasi permasalahan tersebut adalah dengan menerapkan model pembelajaran inovatif. Salah satunya adalah model Problem Solving. Beberapa penelitian terdahulu telah melaksanakan penelitian tentang penerapan model Problem Solving dalam pembelajaran. Kurino (2018) dengan judul Problem Solving Dapat Meningkatkan Hasil Belajar Siswa Pada Materi Operasi Penjumlahan Dan Pengurangan Bilangan Bulat di Kelas V Sekolah Dasar. Pada penelitiannya disimpulkan bahwa penelitian ini telah berhasil, terbukti dengan adanya peningkatan dalam hasil belajar yang optimal, dalam pembelajaran melalui Problem Solving aktivitas anak didik meningkat terbukti dengan nilai rata-rata yang diperoleh naik. Saran dalam penelitian ini adalah untuk meningkatkan hasil belajar anak didik hendaknya guru kreatif, memahami karakteristik anak didik, dan memperhatikan sarana dan prasarana. Sebagai alternatif salah satu pembeajaran yang mendukung akan kreativitas anak maupun guru adalah pendekatan Problem Solving.

Selanjutnya penelitian yang dilakukan oleh Khairani \& Safitri (2017) dengan judul Penerapan Metode Pembelajaran Problem SolvingUntuk Meningkatkan Hasil Belajar Peserta Didik Pada Materi Usaha dan Energi di MAN Rukoh Banda Aceh. Dalam penelitiannya menunjukkan bahwa erdapat pengaruh penerapan metode pembelajaran Problem Solving terhadap hasil belajar peserta didik. N-gain menunjukkankelas eksperimen lebih tinggi, mencapai (100\%) dibandingkan dengan kelas kontrol (55\%). Penerapan metode pembelajaran Problem Solving berpengaruh terhadap aktivitas guru dan peserta didik di MAN Rukoh Banda Aceh yang terlihat lebih aktif dalam mengikuti proses belajar mengajar.

Penelitian ini bertujuan untuk meningkatkan hasil belajar IPS siswa melalui implementasi model pembelajaran Problem Solving siswa kelas VIII-I semester 1 SMP Negeri 4 Seririt.

\section{Metode}

Penelitian ini merupakan Penelitian Tindakan Kelas (PTK) atau Classroom Action Research, yang secara umum merupakan jenis penelitian yang bertujuan memperbaiki kualitas proses pembelajaran di di dalam kelas (Sugiyono, 2014). Penelitian Tindakan Kelas ini dilaksanakan di SMP N 4 Seririt, Kabupaten Buleleng tahun pelajaran 2019/2020. Prosedur penelitian ini terdiri dari (1) tahap perencanaan (planing); (2) tahap tindakan (action); (3) tahap observasi/ evaluasi (evaluation); dan (4) tahap refleksi (reflection), kemudian kembali lagi ke tahap perencanaan, tahap tindakan dan seterusnya sehingga membentuk siklus (Aqib, 2006). Adapun prosedur penelitian tersebut disajikan pada Gambar 1.

\begin{tabular}{l|l|l|}
$\begin{array}{l}\text { Siklus I } \\
\text { (1) Perencanaan 1 } \\
\text { (2) Pelaksanaan Tindakan 1 } \\
\text { (3) Observasi / evaluasi 1 } \\
\text { (4) Refleksi 1 }\end{array}$ & $\begin{array}{l}\text { Siklus II } \\
\text { (1) Perencanaan 2 } \\
\text { (2) Pelaksanaan Tindakan 2 } \\
\text { (3) Observasi / evaluasi 2 } \\
\text { (4) Refleksi 2 }\end{array}$ \\
\hline
\end{tabular}

Gambar 1. Tahapan Tiap siklus

Subjek penelitian ini adalah siswa kelas VIII-I SMP N 4 Seririt tahun pelajaran 2019/2020 yang berjumlah 29 orang terdiri dari 19 siswa laki dan 10 siswa perempuan. Objek tindakan dari penelitian ini adalah Penerapan model pembelajaran Problem Solving sedangkan objek produk dari penelitian ini adalah 
hasil belajar IPS. Penelitian ini dilaksanakan pada semester 1 tahun pelajaran 2019/2020 di SMP Negeri 4 Seririt.

Data yang dikumpulkan dalam penelitian ini adalah data hasil belajar IPS siswa kelas VIII. Data tersebut bersumber dari siswa yang diambil dari hasil evaluasi pada akhir siklus. Data hasil berlajar tersebut dikumpulkan dengan menggunakan metode tes, yaitu dalam bentuk tes objektif. Data hasil belajar IPS siswa dianalisis dengan statistik diskriptif, yaitu dicari rata-ratanya, daya serap dan ketuntasan belajar, selanjutnya untuk mengetahui peningkatan yang terjadi, dapat dilihat dengan indikator $80.00 \%$ tuntas dengan Standar Kreteria ketuntasan Minimal KKM (70).

\section{Hasil dan Pembahasan}

\section{Hasil}

Hasil Kondisi awal subjek penelitian pada penelitian ini adalah kemampuan siswa kelas VIII-I semester 1 SMP Negeri 4 Seririt dalam memahami dan menyelesaikan soal-soal yang berkaitan dengan Materi masih sangat kurang. Data akurat tentang kondisi awal siswa sudah diuraikan pada perolehan hasil belajar dimana rata-ratanya adalah 70,87 , dengan ketuntasan belajar $44,83 \%$, siswa yang perlu diremidi 16 siswa. Data tersebut masih jauh dari standar ketuntasan dengan ketuntasan belajar $80.00 \%$. Hasil yang cukup rendah ini tidak terlepas dari cara pengajaran peneliti masih sangat kurang, belum menyiapkan segala sesuatunya dengan baik, belum membaca teori-teori para ahli yang benar, masih tradisional dan konvensional.

Pelaksanaan tindakan I dilaksanakan selama 3 kali pertemuan, seperti yang telah direncanakan, yaitu tanggal 13 sampai 20 Agustus 2019 di ruang kelas VIII-I SMP Negeri 4 Seririt, setiap pertemuan dilaksanakan 2 X 40 Menit sesuai dengan skenario pembelajaran dan RPP. Materi pada pelaksanaan tindakan I ini adalah (Interaksi keruangan dalam kehidupan di negara-negara ASEAN). Pada pertemuan pertama, guru menjelaskan materi tentang letak geografis Negara-negara ASEAN. Pertemuan kedua, siswa diminta untuk melaksanakan diskusi dan presentasi dengan model pembelajara Problem Solving. Pertemuan ketiga diisi dengan evaluasi belajar siswa dari siklus I. Berdasarkan hasil refleksi yang telah dilakukan pada siklus I didapatkan hasil bahwa terjadi peningkatan dari rata-rata $(70,87)$ menjadi $(76,56)$, dan prosentase ketuntasan $(44,83 \%)$ menjadi $(68,97 \%)$. Jumlah siswa yang Tidak Tuntas sebanyak 16 orang dan pada siklus satu yang tidak tuntas sebanyak 9 orang yang belum mencapai KKM.

Peningkatan nilai dari data awal ke siklus I, memang merupakan kosekuensi logis dari implementasi strategi pembelajaran yang diterapkan karena telah dipersiapkan secara matang pada tahap perencanaan, diimplementasikan sesuai dengan sintaknya pada tahap pelaksanaan dan observasi yang telah dilaksanakan. Dikatakan demikian, karena pembelajaran dilaksanakan secara alamiah tanpa adanya manipulasi atau perlakuan secara istimewa. Dari data tersebut dapat diberikan gambaran bahwa pada siklus I ternyata hasilnya belum sesuai harapan, hasil tersebut memberikan gambaran adanya kekurangan atau kelemahan dalam proses pelaksanaan pembelajaran yaitu masih dibutuhkan waktu lebih lama untuk menanamkan pengetahuan menggunakan model Problem Solving. Untuk pada bagian ini disampaikan kekurangan-kekurangan/kelemahan-kelemahan yang ada serta kelebihan-kelebihannya seperti berikut.

Kekurangan/kelemahan yang ada dari pelaksanaan tindakan siklus I guru belum memberikan waktu yang lebih lama bagi peserta didik dalam melaksanakan metode yang diterapkan. Mengingat kemampuan siswa yang berbeda dalam menyerap pembelajaran, krena ada siswa yang cepat menerima dan ada sebagian yang lambat; guru kuarang memberikan penghargaan kepada anak yang berhasil serta belum maksimal dalam memotivasi siswa; belum menguasai model-model yang konstruktivisme; belum mampu mengubah cara pengajaran menjadi pembelajaran, masih berpusat pada guru; dalam tanya jawab belum menggunakan tanya jawab multi arah. Sedangkan kelebihan yang ditemukan pada pelaksanaan tindakan siklus I adalah guru telah berupaya keras untuk menyiapkan segala sesuatunya agar pembelajaran dapat berjalan lancar; perbaikan kelemahan guru dalam menggunakan model Problem Solving diupayakan membaca teori lebih banyak; kekurangan yang telah disampaikan akan dibenahi selanjutnya pada siklus II.

Pelaksanaan tindakan II dilaksanakan selama 3 kali pertemuan, seperti yang telah direncanakan, yaitu tanggal 3 September, 4 September dan 10 September 2019 di ruang kelas VIII-I SMP Negeri 4 Seririt. Setiap pertemuan dilaksanakan selama 2 x 40 menit sesuai dengan skenario pembelajaran dan RPP. Materi pada pelaksanaan tindakan II ini adalah Interaksi antar Negara-negara ASEAN. Pada pertemuan pertama, guru menjelaskan materi ASEAN secara umum. Kemudian pada pertemuan kedua, siswa diminta untuk melaksanakan diskusi dan presentasi dengan model pembelajaran Problem Solving. Pertemuan ketiga diisi dengan evaluasi belajar siswa dari siklus II. Pada siklus II terjadi peningkatan dari rata-rata $(76,56)$ pada siklus 1 menjadi $(80,39)$ pada siklus II, dan prosentae ketuntasan dari $(68,97 \%)$ pada siklus 1 menjadi $(89,66 \%)$ pada siklus II. Jumlah siswa yang Tidak Tuntas pada siklus I sebanyak 9 orang dan 
pada siklus II yang tidak tuntas sebanyak 3 orang yang belum mencapai KKM disebabkan oleh adanya kemampuan siswa dimaksud memang perlu bimbingan secara khusus.

Dengan demikian secara keseluruhan dapat di simpulkan bahwa penerapan model Problem Solving pada kelas VIII-I SMP Negeri 4 seririt Tahun Pelajaran 2019/2020 adalah berhasil dan dapat dipertanggungjawabkan hasilnya karena sudah mencapai standar ketuntasan yang diharapkan penulis yaitu dengan KKM 70 dengan (80.00\%).

\section{Pembahasan}

Hasil penelitian ini sejalan dengan hasil penelitian yang dilakukan oleh Kurino (2018), Sukaisih \& Muhali (2014), dan Sutarmi \& Suarjana (2017). Pada penelitian-penelitian tersebut disimpulkan bahwa penelitian ini telah berhasil, terbukti dengan adanya peningkatan dalam hasil belajar yang optimal, dalam pembelajaran melalui Problem Solving aktivitas anak didik meningkat terbukti dengan nilai rata-rata yang diperoleh naik. Saran dalam penelitian ini adalah untuk meningkatkan hasil belajar anak didik hendaknya guru kreatif, memahami karakteristik anak didik, dan memperhatikan sarana dan prasarana. Sebagai alternatif salah satu pembeajaran yang mendukung akan kreativitas anak maupun guru adalah pendekatan Problem Solving.

Selanjutnya penelitian yang dilakukan oleh Khairani \& Safitri (2017), dan Yuwono (2016). Dalam penelitiannya menunjukkan bahwa erdapat pengaruh penerapan metode pembelajaran Problem Solving terhadap hasil belajar peserta didik. N-gain menunjukkankelas eksperimen lebih tinggi, mencapai $(100 \%)$ dibandingkan dengan kelas kontrol(55\%). Penerapan metode pembelajaran Problem Solving berpengaruh terhadap aktivitas guru dan peserta didik di MAN Rukoh Banda Aceh yang terlihat lebih aktif dalam mengikuti proses belajar mengajar.

Beberapa manfaat yang dapat diambil dari penelitian ini yaitu : (1) Penerapan Model Problem Solving dapat memberikan pengalaman baru dan menyenangkan baik bagi guru maupun siswa; (2) siswa dapat melakukan pengulangan dalam pembelajaran sehingga meningkatkan pemahaman siswa terhadap sains dan akan lebih tertarik terhadap pembelajaran; (3) siswa dapat mengejar ketertinggalan pengetahuan tentang Iptek di bidang pendidikan; (4) dapat meningkatkan motivasi belajar para pembelajar sehingga peserta didik tidak merasa bosan dan terjadi proses pembelajaran yang menyenangkan; dan (5) dapat digunakan untuk membantu membentuk model mental yang akan memudahkan pembelajar memahami suatu konsep.

\section{Simpulan dan Saran}

Berdasarkan hasil penelitian dan pembahasan terkait dengan Implementasi Model Problem Solving untuk meningkatkan Hasil belajar Siswa dalam pelajaran IPS kelas VIII-I SMP Negeri 4 Seririt tahun pelajaran 2019/2020 maka dapat disimpulkan bahwa adanya peningkatan dari rata-rata $(76,56)$ pada siklus 1 menjadi $(80,39)$ pada siklus II, dan prosentae ketuntasan dari $(68,97 \%)$ pada siklus 1 menjadi $(89,66 \%)$ pada siklus II. Perolehan data ini sudah mencapai standard ketuntasan yang diharapkan penulis yaitu dengan KKM 70. Penelitian Tindakan Kelas (PTK) penerapan model pembelajaran Problem Solving sebagai upaya meningkatkan hasil belajar siswa kelas VIII-I pada mata pelajaran IPS Terpadu di SMP N 4 Seririt Tahun Pelajaran 2019/2020 adalah berhasil dan dapat dipertanggungjawabkan hasilnya. Hal ini dikarenakan PTK telah dilaksanakan sesuai dengan prosedur penelitian. Implementasi Model Pembelajaran Problem Solving mampu meningkatkan Hasil Belajar IPS, untuk itu ada beberapa saran yang bisa dijadikan sebagai bahan untuk perbaikan selanjutnya, yaitu: kepada guru IPS agar mencoba mengimplementasikan Model Pembelajaran Problem Solving sebagai model pembelajaran, sebagai upaya untuk meningkatkan Hasil Belajar IPS Siswa. Kepada pembaca, jika berkeinginan melakukan penelitian lebih lanjut sehubungan dengan Implementasi Model Pembelajaran Problem Solving diharapkan dapat mengembangkan model pembelajaran tersebut pada keterampilan berbahasa yang lain dengan topik yang berbeda pula. Selanjutnya, kendala-kendala dan kelemahankelemahan dalam penelitian ini dapat terpecahkan dengan baik.

\section{Daftar Rujukan}

Hamdu, G., \& Agustina, L. (2011). Pengaruh Motivasi Belajar Siswa Terhadap Prestasi Belajar IPA Di Sekolah Dasar. Jurnal Penelitian Pendidikan, 12(1), 90-96. https://www.academia.edu/download/35968572/8-Ghullam_Hamdu1.pdf.

Harefa, D. (2020). Pengaruh Model Pembelajaran Problem Solving Terhadap Hasil Belajar IPA Fisika Siswa Kelas IX SMP Negeri 1 Luahagundre Maniamolo Tahun Pembelajaran (Pada Materi Energi Dan 
Daya Listrik). Jurnal Education and Development, 8(1), 231-231. http://journal.ipts.ac.id/index.php/ED/article/view/1540.

Heriyansyah, H. (2018). Guru Adalah Manajer Sesungguhnya Di Sekolah. Islamic Management: Jurnal Pendidikan Islam,

1(01). http://jurnal.staialhidayahbogor.ac.id/index.php/jim/article/download/218/201.

Irawati, R. K. (2014). Pengaruh Model Problem Solving dan Problem Posing serta Kemampuan Awal terhadap Hasil Belajar Siswa. Jurnal Pendidikan Sains, 2(4), 184-192. http://repository.um.ac.id/id/eprint/60053.

Jauhar, S., \& Nurdin, M. (2017). Penerapan Model Pembelajaran Problem Solving Dalam Meningkatkan Hasil Belajar IPS Siswa SD. JIKAP PGSD: Jurnal Ilmiah Ilmu Kependidikan, 1(2), 141-149. https://doi.org/10.26858/jkp.v1i2.5285.

Juhji, J. (2016). Peran Urgen Guru dalam Pendidikan. Studia Didaktika, 10(01), 51-62. http://www.jurnal.uinbanten.ac.id/index.php/studiadidaktika/article/view/73.

Khairani, I., \& Safitri, R. (2017). Penerapan Metode Pembelajaran Problem Solving Untuk Meningkatkan Hasil Belajar Peserta Didik Pada Materi Usaha dan Energi di MAN Rukoh Banda Aceh. Jurnal Pendidikan Sains Indonesia (Indonesian Journal of Science Education), 5(2), 32-40. https://doi.org/10.24815/jpsi.v5i2.9814.

Kurino, Y. (2018). Problem Solving Dapat Meningkatkan Hasil Belajar Siswa Pada Materi Operasi Penjumlahan Dan Pengurangan Bilangan Bulat Di Kelas V Sekolah Dasar. Jurnal Cakrawala Pendas, 4(1). http://dx.doi.org/10.31949/jcp.v4i1.706.

Malisa, S., Bakti, I., \& Iriani, R. (2018). Model Pembelajaran Creative Problem Solving (CPS) Untuk Meningkatkan Hasil Belajar Dan Kemampuan Berpikir Kreatif Siswa. Vidya Karya, 33(1), 1-20. http://dx.doi.org/10.20527/jvk.v33i1.5388.

Musa, M. I. (2016). Pengembangan Kompetensi Guru Terhadap Pelaksanaan Tugas Dalam Mewujudkan Tenaga Guru Yang Profesional. Jurnal Pesona Dasar, 2(4). http://www.erepository.unsyiah.ac.id/PEAR/article/view/7529.

Nurkholis, N. (2013). Pendidikan dalam upaya memajukan teknologi. Jurnal kependidikan, 1(1), 24-44. https://doi.org/10.24090/jk.v1i1.530.

Oktiani, I. (2017). Kreativitas Guru dalam Meningkatkan Motivasi Belajar Peserta Didik. Jurnal Kependidikan, 5(2), 216-232. https://doi.org/10.24090/jk.v5i2.1939.

Purwanti, S., \& Manurung, S. (2015). Analisis Pengaruh Model Pembelajaran Problem Solving dan Sikap Ilmiah Terhadap Hasil Belajar Fisika. Jurnal Pendidikan Fisika, 4(1), 57-62. https://doi.org/10.22611/jpf.v4i1.2569.

Sugiyono. (2014). Metode Penelitian Pendidikan Pendekatan Kuantitatif, Kualitatif, dan R\&D. Alfabeta.

Suhendri, H. (2015). Pengaruh metode pembelajaran problem solving terhadap hasil belajar matematika ditinjau dari kemandirian belajar. Formatif: Jurnal Ilmiah Pendidikan MIPA, 3(2). http://dx.doi.org/10.30998/formatif.v3i2.117.

Sukaisih, R., \& Muhali, M. (2014). Meningkatkan kesadaran metakognitif dan hasil belajar siswa melalui penerapan pembelajaran problem solving. Prisma Sains: Jurnal Pengkajian Ilmu dan Pembelajaran Matematika dan IPA IKIP Mataram, 2(1), 71-82. https://doi.org/10.33394/j-ps.v2i1.803.

Sumiati, S. (2018). Peranan Guru Kelas Dalam Meningkatkan Motivasi Belajar Siswa. TARBAWI: Jurnal $\begin{array}{llll}\text { Pendidikan Agama } & \text { Islam, }\end{array}$ https://jurnal.unismuh.ac.id/index.php/tarbawi/article/view/1599.

Sutarmi, K., \& Suarjana, I. M. (2017). Peningkatan Hasil Belajar Siswa Menggunakan Metode Problem Solving dalam Pembelajaran. Jurnal Ilmiah Sekolah Dasar, 1(2), 75-82. http://dx.doi.org/10.23887/jisd.v1i2.10141.

Warsono, W. (2017). Guru: antara pendidik, profesi, dan aktor sosial. The Journal of Society and Media, 1(1), 1-10. http://dx.doi.org/10.26740/jsm.v1n1.p1-10.

Yuliati, Y., \& Lestari, I. (2019). Penerapan Model Creative Problem Solving untuk Meningkatkan Hasil Belajar Siswa pada Pembelajaran Ilmu Pengetahuan Alam Di Sekolah Dasar. Jurnal Cakrawala Pendas, 5(1). http://dx.doi.org/10.31949/jcp.v5i1.1200.

Yuwono, A. (2016). Problem solving dalam pembelajaran matematika. UNION: Jurnal Ilmiah Pendidikan Matematika, 4(1). http://dx.doi.org/10.30738/.v4i1.420. 